\title{
HIV-1 Induces the First Signal to Activate the NLRP3 Inflammasome in Monocyte-Derived Macrophages
}

\author{
Juan C. Hernandez ${ }^{a} \quad$ Eicke Latz $^{\mathrm{b}, \mathrm{c}}$ Silvio Urcuqui-Inchima ${ }^{\mathrm{d}}$ \\ ${ }^{a}$ Infettare, Facultad de Medicina, Universidad Cooperativa de Colombia, Medellin, Colombia; ${ }^{b}$ Department of \\ Infectious Diseases and Immunology, University of Massachusetts Medical School, Worcester, Mass., USA; ${ }^{C}$ Institute of \\ Innate Immunity, University Hospitals, University of Bonn, Bonn, Germany; ${ }^{\mathrm{d}}$ Grupo Inmunovirologia, Universidad de \\ Antioquia, Medellin, Colombia
}

\section{Key Words}

HIV-1 · NLRP3 inflammasome $\cdot$ IL-1 $\beta$. Macrophages ·

Inflammation

\begin{abstract}
Background/Aims: Inflammasomes are multimolecular complexes that regulate caspase-1. They act as sensors for endogenous and exogenous signals, and mediate the processing of pro-IL-1 $\beta$ into its secreted, biologically active form. The NLRP3 inflammasome and IL-1 $\beta$ are particularly interesting because they are required for efficient control of viral infections. Indeed, HIV-1 induces expression of NLRP3 and IL-1 $\beta$ in healthy controls, but not in HIV-1-infected patients. Here we evaluate whether HIV-1 can induce activation of the NLRP3 inflammasome. Methods: Human primary monocyte-derived macrophages were infected with HIV-1 in the absence or presence of classical NLRP3 inflammasome activators, and IL- $1 \beta$ release was assessed by ELISA. Results: HIV-1 initiates the priming signal for NLRP3 inflammasome activation through the NF-kB-associated pathway in human primary monocyte-derived macrophages. Furthermore, priming of NLRP3 activation in response to HIV-1 was independent of the viral envelope, since similar results were ob-
\end{abstract}

served with HIV-1 and pseudotyped HIV-1 lacking the env gene. Conclusion: Our findings suggest that HIV-1 infection promotes IL-1 $\beta$ secretion by inducing the first signal for NLRP3 inflammasome activation, a phenomenon that may contribute to AIDS progression.

Copyright $\odot 2013$ S. Karger AG, Basel

\section{Introduction}

Alterations in the mechanisms responsible for the control of inflammation have been associated with pathological events. The inflammatory process is highly controlled and IL- $1 \beta$ plays a central role in this process. The production of IL- $1 \beta$ requires two signals: (i) transcriptional activation mediated by $N F-\kappa B$, which in turn is activated by one of the pattern recognition receptors such as the Toll-like receptors (TLR) [1], and (ii) proteolytic maturation promoted by cytoplasmic complexes called inflammasomes [2]. To date, four inflammasomes have been identified [3], three of which contain proteins of the NOD-like receptor family, including NLRP1, NLRP3 and NLRC4. The fourth inflammasome contains AIM2 that belongs to the pyrin domain and HIN200 domain-con-

\section{KARGER}

E-Mail karger@karger.com

www.karger.com/int
(C) 2013 S. Karger AG, Basel

0300-5526/14/0571-0036\$39.50/0
J.C. Hernandez

Infettare, Facultad de Medicina

Universidad Cooperativa de Colombia

Medellín (Colombia)

E-Mail juankhernandez@gmail.com 
taining family [4-7]. All the inflammasome-forming receptor proteins use the adaptor molecule ASC to recruit and efficiently activate caspase- 1 in response to several pathogen- or damage-associated molecular patterns $[1,4$, $8-13$ ]. Inflammasome activation leads to the cleavage of pro-IL-1 $\beta$, to produce the biologically active form, IL-1 $\beta$. Other stimuli that activate the NLRP3 inflammasome include ATP, $\beta$-amyloid [8], crystals [14, 15], asbestos, sili$\mathrm{ca}$, aluminum salts $[9,16]$, residues of necrosis [17] and nanoparticles $[18,19]$.

The mechanism involved in activating the NLRP3 inflammasome is not well understood. Some studies have proposed a key role of cathepsins (lysosomal proteases) in this process $[8,9,16]$. A second model is based on reactive oxygen species, which could be sensed by the NLRP3 inflammasome [20,21]. Additionally, it has been reported that alterations in the efflux of potassium [20$23]$ and calcium mobilization $[24,25]$ are responsible for NLRP3 inflammasome activation.

Several viruses can activate caspase- 1 and induce IL- $1 \beta$ secretion, highlighting the potential role of the NLRP3 inflammasome in antiviral immune responses [12, 2628]. However, there are few reports about HIV-1 and inflammasomes, including the association between $3^{\prime} \mathrm{UTR}$ polymorphism in NLRP3 and the susceptibility to HIV-1 infection [29]. It was recently reported that HIV-1 induces expression of the mRNA of NLRP3, IL- $1 \beta$ and caspase-1 in dendritic cells from healthy donors, but not from HIV-1-infected patients [30]. In addition, HIV1 -infected patients show a pro-inflammatory stage with immune hyperactivation, including higher levels of IL- $1 \beta$ in the serum, which could indeed be explained by the microbial translocation [31-34] (online suppl. S1; for all online suppl. material, see www.karger.com/doi/10.1159/ 000353902). However, a direct relationship between HIV-1 and NLRP3 inflammasome activation has not been demonstrated. Here, we show that HIV-1 activates the 'priming' signal for NLRP3 inflammasome activation through NF- $\kappa B$ signaling, and leads to IL- $1 \beta$ secretion in the presence of specific NLRP3 inflammasome triggers.

\section{Material and Methods}

\section{Cell Cultures}

Human primary monocyte-derived macrophages (MDM) obtained from healthy donors were used here. Human macrophages were used because they are a cellular target for HIV-1 infection in which NLRP3 inflammasome activation has been previously studied. CD14+ monocytes were acquired by elutriation from PBMCs [35]. Differentiation into macrophages was obtained after 7 days of culture at $37^{\circ}$ and $5 \% \mathrm{CO}_{2}$ in the presence of $10 \mathrm{ng} / \mathrm{ml} \mathrm{GM}$-CSF (PeproTech). Monocyte differentiation into MDM was confirmed by flow cytometry on an LSR II flow cytometer (BD Biosciences) and analyzed using FlowJo software (Tree Star, Inc.), using macrophage markers (CD68/CD14) (data not shown). In all the reagents used no endotoxin could be detected, using the Limulus amebocyte lysate (LAL) assay (data not shown).

\section{Viruses}

293T cells were transfected with 100 ng of pNL4-3 or pNL4$3 \Delta$ env in the presence of the pVSV-G envelope vector (vesicular stomatitis virus glycoprotein G), using GeneJuice (EMD4Biosciences, San Diego, Calif., USA). After $48 \mathrm{~h}$, the supernatant was harvested and filtered through $0.22-\mu \mathrm{m}$ filters. This strategy yielded two types of viruses: HIV-1 $1_{\mathrm{VSV}-\mathrm{G}}$ and the pseudotyped HIV$1 \Delta$ env $_{\text {VSV-G. }}$. This means that HIV-1 with or without envelope glycoproteins and both with VSV-G to increase the efficiency of infection, reaching $60 \%$ in all the experiments, compared to $2-4 \%$ without VSV-G protein, as previously reported [36-38]. Viral titers were quantified by a radioactive reverse transcriptase assay, to determine the amount of infectious particles [39]. Viral stocks were treated with DNase-I to remove residual DNA, as previously described [40].

\section{In vitro HIV-1 Infections and NLRP3 Inflammasome}

Stimulation

Differentiated MDM were stimulated to evaluate both signals of NLRP3 inflammasome stimulation as previously reported [1]. In brief, priming was initiated with $50 \mathrm{pg} / \mathrm{ml}$ LPS or with a pulse of HIV-1 $1_{\text {VSV-G }}$ or HIV-1 1 env $_{\mathrm{VSV}-\mathrm{G}}(300,000$ reverse transcriptase units (RTU)). Triggers of the second signal were added $2 \mathrm{~h}$ later: $5 \mathrm{mM}$ ATP, $10 \mu \mathrm{M}$ nigericin, $50 \mu \mathrm{g} / \mathrm{ml}$ silica, $100 \mathrm{mg} / \mathrm{ml}$ alum, 20 $\mu \mathrm{g} / \mathrm{ml}$ monosodium urate crystals (MSU), and $1 \mu \mathrm{M}$ R848 or 100 $\mathrm{ng} / \mathrm{ml} \mathrm{LPS}$, for $4 \mathrm{~h}$ (1 $\mathrm{h}$ for ATP and nigericin) [41]. In addition, HIV-1 was also used to stimulate the second signal.

\section{ELISA}

IL- $1 \beta$ and IL- 6 secretion was quantified using ELISA (BD Biosciences) and expressed as $\mathrm{pg} / \mathrm{ml}$. IL- $1 \beta$ detection was performed in the supernatants to quantify only the processed form of the cytokine.

\section{Results}

HIV-1 Induces the Production of IL-1 $\beta$ in Response to NLRP3 Inflammasome Agonists

MDMs primed with LPS, HIV-1 $1_{\text {VSV-G }}$ or HIV$1 \Delta$ env $_{\mathrm{VSV}-\mathrm{G}}$ and then treated with NLRP3 inflammasome activators secreted high levels of IL-1 $\beta$ (fig. 1). HIV$1 \Delta$ env VSV-G $_{\text {Was }}$ used to compare the effects of HIV-1 priming in the absence of the envelope glycoproteins. Interestingly, a similar IL- $1 \beta$ production in response to LPS or HIV-1 and the classical NLRP3 inflammasome activators was detected. No IL- $1 \beta$ production was observed in MDM stimulated only with the priming signal or with inducers of the second signal in the absence of priming. 
Fig. 1. HIV-1 induces the production of IL$1 \beta$ in response to NLRP3 inflammasome activators. MDMs were primed with LPS $(50 \mathrm{pg} / \mathrm{ml})$ or HIV-1 (HIV-1 ${ }_{\mathrm{VSV}-\mathrm{G}}$ or HIV$1 \Delta$ env $\left._{\text {VSV-G }}\right)(300,000$ RTU) for $2 \mathrm{~h}$. Subsequently, the cells were treated with activators of the second signal for NLRP3 inflammasome: ATP $(5 \mathrm{mM})$, nigericin $(10 \mu \mathrm{M})$, silica $(50 \mu \mathrm{g} / \mathrm{ml})$, alum $(100 \mathrm{mg} / \mathrm{ml})$ and MSU $(20 \mu \mathrm{g} / \mathrm{ml})$. Four hours later the production of IL-1 $\beta$ was quantified in the supernatants by ELISA. Representative results of three independent experiments are shown as mean and standard deviation. Comparisons were performed using the KruskalWallis ANOVA tests and Dunn's post-tests. The level of significance was $* \mathrm{p}<0.05$.

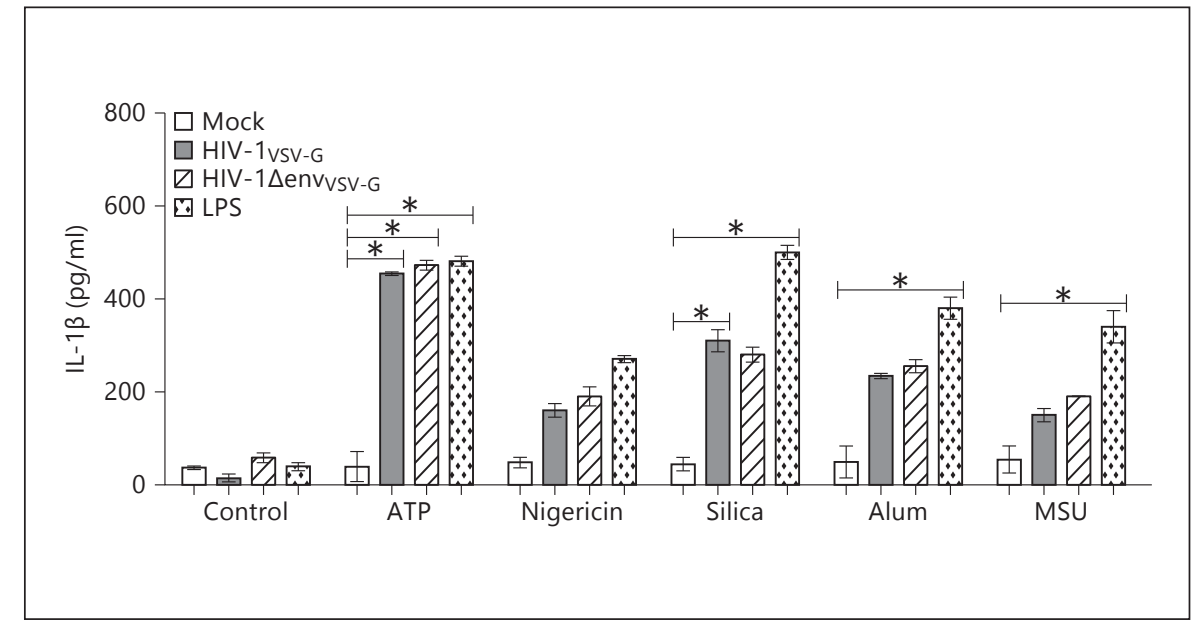

Furthermore, no differences were detected in the secretion of IL- $1 \beta$ based on the viral type used, HIV-1 $1_{\text {VSV-G }}$ or HIV-1 1 env $_{V S V-G}$ (fig. 1). Similar results were observed in response to silica, alum or MSU, but in these cases, IL-1 $\beta$ production was greater when LPS was used as priming signal compared to HIV-1 primed cells (fig. 1). Moreover, in the absence of a second signal activator, HIV-1 was unable to induce IL-1 $\beta$ release (fig. 1). These results suggest that HIV-1 can induce at least one of the two signals for NLRP3 inflammasome activation in vitro.

\section{HIV-1 Fails to Induce the Second Signal for NLRP3 Inflammasome Activation}

To determine whether HIV-1 stimulates the second signal involved in NLRP3 inflammasome activation, MDMs were primed with LPS (50 pg/ml) or HIV-1 VsV-G or HIV-1 1 env VSV-G $_{\text {Vor }} 2 \mathrm{~h}$. The cells were then treated with activators of the second signal for the NLRP3 inflammasome [42], as well as HIV-1 $1_{\text {VSV-G. }}$ Our results show that when HIV-1 was used as priming and second signal, the MDMs were unable to secret IL- $1 \beta$, suggesting failure to activate the NLRP3 inflammasome. In contrast, classical inflammasome activators such as ATP and silica, and alternative activators such as LPS (100 ng/ml) and R848, induced higher IL-1 $\beta$ production than HIV-1 (fig. 2a). These results suggest that early phases of HIV-1 infection are unable to induce the second signal for NLRP3 inflammasome activation.

HIV-1 Induces the Activation of NF- $\kappa B$, as

Determined by IL-6 Production

The induction of the first signal for NLRP3 inflammasome activation requires the activation of NF- $\kappa \mathrm{B}$, whose signaling triggers the expression of molecules including NLRP3, pro-IL- $1 \beta$ and IL-6 [1]. Therefore, the ability of HIV-1 to stimulate NF- $\kappa B$ signaling was determined by quantifying IL- 6 production by MDM. As shown in figure $2 b$, the stimulation of MDM with HIV-1 as the first signal (fig. 2b) induced the production of IL-6 to a similar level as LPS. As one would expect, ATP and MSU do not have a notorious effect on IL-6 release, but TLR stimulation induces a higher production of IL-6, even in the absence of the priming signal. These results indicate that HIV -1 can activate the production of IL- 6 through NF- $\kappa B$ signaling, which is in agreement with the results presented in figure 2a. Thus, HIV-1 activates the first signal for NLRP3 inflammasome through the NF- $\kappa B$ signaling pathway.

\section{Discussion}

The NLRP3 inflammasome is one of the components involved in the inflammatory process and constitutes a new member of the innate immune system receptors involved in virus recognition, although its relationship with HIV-1 is only beginning to be studied. Indeed, Pontillo et al. [30] have described that HIV-1 induces the expression of NLRP3 inflammasome components and IL- $1 \beta$ secretion in dendritic cells from healthy individuals but not from HIV-1-infected patients, suggesting a role of the inflammatory process in disease progression. Furthermore, it has been reported that the plasma of HIV-1-infected patients presents increased IL-1 $\beta$ levels during all the stages of infection ([33] and online suppl. S1). However, the mechanism involved in 
Fig. 2. HIV-1 induces the production of IL-6 in MDM, but does not activate the second signal for NLRP3 inflammasome activation. MDMs were primed with LPS (50 $\mathrm{pg} / \mathrm{ml}$ ) or HIV-1 (HIV-1 $1_{\mathrm{VSV}-\mathrm{G}}$ or HIV$1 \Delta$ env $_{\text {VSV-G }}$ ) for $2 \mathrm{~h}$. Subsequently, the cells were treated with classical activators of the second signal for NLRP3 inflammasome: ATP $5 \mathrm{mM}$, MSU $20 \mu \mathrm{g} / \mathrm{ml}$, silica $50 \mu \mathrm{g} / \mathrm{ml}$, with LPS $100 \mathrm{ng} / \mathrm{ml}$ (TLR4 ligand), R848 $1 \mu \mathrm{M}$ (TLR7 ligand), or with HIV-1 $1_{\mathrm{VSV}-\mathrm{G}}$ 300,000 RTU. Four hours later the production of IL-1 $\beta$ (a) and IL-6 (b) was quantified in the supernatants by ELISA. Representative results of three independent experiments are shown as mean and standard deviation. Comparisons were performed using Kruskal-Wallis ANOVA tests and Dunn's post-tests. The level of significance was $* \mathrm{p}<0.05$.

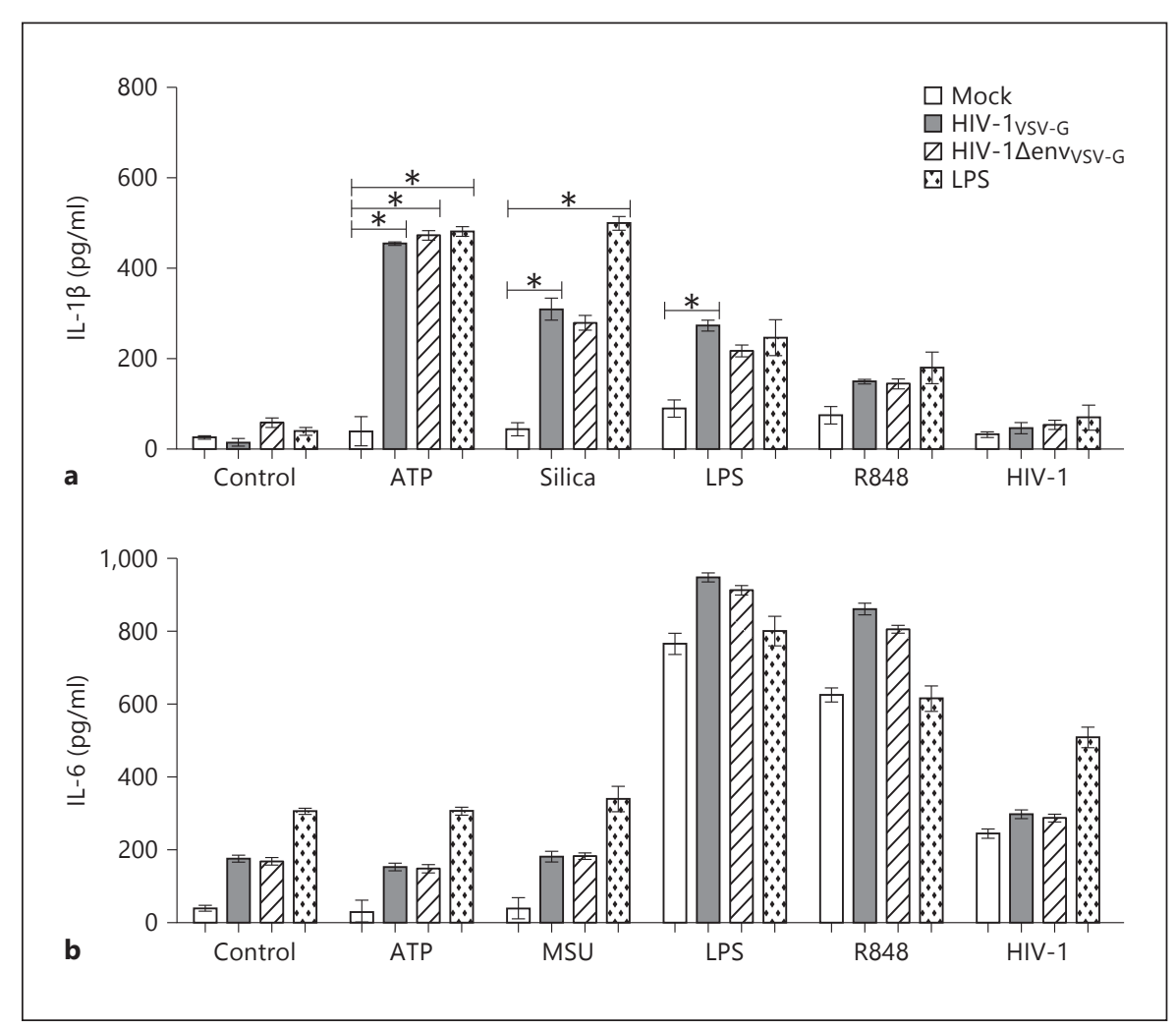

the recognition of HIV-1 by the NLRP3 inflammasome is not well understood. Here we show that HIV-1 induces the first signal required for NLRP3 inflammasome activation, since high levels of IL- $1 \beta$ secretion were detected in the supernatants of MDM stimulated with HIV-1 as priming signal, and the classical agonists of NLRP3 inflammasome as second signal (fig. 1). These results indicate that HIV-1 induces the assembly of the active NLRP3 inflammasome that leads to IL- $1 \beta$ production in the presence of specific NLRP3 inflammasome triggers. Indeed, during early moments of HIV1-cell interactions, a specific expression of the NLRP3 inflammasome components occurs in dendritic cells [33]. This mechanism could help HIV-1 for acute replication and spread. During the chronic phase, other mechanisms are also implicated in the HIV-1 replication and progression, as immune hyperactivation, microbial translocation, or immunosuppression, among other things. However, when HIV-1 was used as priming and second signal, the MDMs were unable to produce IL-1 $\beta$ (fig. $2 \mathrm{a}$ ). Together the results suggest that HIV-1 acts as priming signal to activate the NLRP3 inflammasome, but is not sufficient to induce IL- $1 \beta$ production on its own. HIV-1 infection is a multifactorial event that may be modulated by several components in the host, environment and the virus itself.

It has been reported that the NLRP3 inflammasome can be activated in response to both RNA and DNA [4, 43]. Since the HIV-1 genome consists of two RNA molecules that in turn are reverse transcribed into a cDNA molecule, these replication intermediates are real candidates for the activation of the NLRP 3 inflammasome. The experiments presented here do not allow us to assess whether viral replication could affect activation of the NLRP3 inflammasome. However, they indicate that exposure to $\mathrm{HIV}-1$ was sufficient to activate NF- $\kappa \mathrm{B}-$ mediated intracellular signaling and subsequent IL-6 production, consistent with previous studies showing cellular activation and inflammatory response induced by viral components, such as gp120 and the genomic RNA $[44,45]$. Our results also indicate that activation of the NLRP3 inflammasome is independent of the HIV-1 envelope protein, since similar results were observed in MDM stimulated with HIV-1 $1_{\text {VSV-G }}$ or HIV-1 1 env $_{\text {VSV-G. }}$. The NLRP 3 inflammasome can be activated by viruses or their products [46], including varicella-zoster virus [47], influenza virus $[12,27]$, hepatitis $C$ virus [48] and adenovirus type $5[49,50]$. In addition to viral models, other 
infectious agents have been associated with NLRP3 inflammasome activation, including immunopathogenesis mechanisms, such as Aeromonas spp. [51] and Borrelia spp. [52] that induce the expression of IL-1 $\beta$ and IL-18, altering the development of inflammatory immune response. Several microorganisms could be present during the course of HIV-1 due to an immunosuppression state, as well as PAMPs, associated to microbial products translocation from gut, which is a key feature in HIV-1 pathogenesis. However, some microorganisms can also block the activation of the NLRP3 inflammasome to favor their persistence in the host. For instance, the viral protein Orf63 of Kaposi's sarcoma-associated herpesvirus acts as a viral homologue of NLRP1, blocking the function of the NLRP1 and NLRP3 inflammasomes, decreasing the inflammatory response, and promoting viral reactivation [53]. In terms of endogenous ligands, the cholesterol crystals could be present in HIV-1-infected patients, taking into account the increased risk of cardiovascular diseases among these patients, due to high cholesterol levels in serum [54-56].

Little is known regarding the relationship between HIV-1 and inflammasomes. There is increased expression of IL-1 $\beta$ in HIV-1-infected individuals [31, 32, 34], but information about the mechanisms that promote IL$1 \beta$ production is sparse. It has also been reported that susceptibility to HIV-1 infection could be associated with polymorphisms in the $3^{\prime} U T R$ of NLRP3 [29]; this is the first report that correlates the NLRP3 inflammasome and HIV-1 in macrophages, although no functional studies have been performed. A better understanding of this pathway will advance the development of new strategies against HIV-1 infection. Our results suggest that HIV-1 is able to act as a first signal inducer for NLRP3 inflammasome activation, which could serve in the development of new therapeutic agents to enhance current antiviral strategies. However, our results also show that HIV1 could not induce the second signal for NLRP3 inflammasome activation, in contrast to the results observed with classical (ATP/silica) and non-classical (LPS/ R848) activators that induce IL- $1 \beta$ production in primed MDMs. Consistent with previous reports [57], this study shows that HIV-1 activates NF- $\kappa B$ intracellular signaling as determined by IL- 6 production. They support the hypothesis concerning the role of HIV-1 in the induction of the first signal, since NF- $\kappa B$ is responsible for activating the transcription of the genes encoding NLRP3 inflammasome components, such as pro-IL- $1 \beta$ and NLRP3.

\section{Conclusion}

These results extend our understanding of the mechanisms of evasion or even exploitation of the immune response to favor viral persistence and pathogenesis. While the work reported here establishes the early phase of HIV-1 infection, as an important priming signal, additional studies are needed for a comprehensive understanding of the NLRP3 inflammasome in the pathogenesis of HIV-1.

\section{Acknowledgements}

We acknowledge the help of Gloria Vásquez, Cherilyn Sirois and Anne-Lise Haenni for critically reviewing the manuscript. The authors also acknowledge the technical assistance of Joana Monteiro and Ann Dauphin of the University of Massachusetts Medical School, Worcester, Mass., USA. Finally, the authors acknowledge the contribution of Mario Stevenson of the Developmental Center for AIDS Research, University of Miami, Miami, Fla., USA, for supplying several reagents. This study was supported by COLCIENCIAS, grant No. 111549326099.

\section{Disclosure Statement}

The authors have no conflicts of interest to disclose.

\section{References}

1 Bauernfeind FG, Horvath G, Stutz A, Alnemri ES, MacDonald K, Speert D, FernandesAlnemri T, Wu J, Monks BG, Fitzgerald KA, Hornung V, Latz E: Cutting edge: NF- $\kappa \mathrm{B}$ activating pattern recognition and cytokine receptors license NLRP3 inflammasome activation by regulating NLRP3 expression. J Immunol 2009;183:787-791.

-2 Dinarello CA: IL-1: discoveries, controversies and future directions. Eur J Immunol 2010; 40:599-606.
Stutz A, Golenbock DT, Latz E: Inflammasomes: too big to miss. J Clin Invest 2009;119: 3502-3511.

4 Martinon F, Mayor A, Tschopp J: The inflammasomes: guardians of the body. Annu Rev Immunol 2009;27:229-265.

5 Fernandes-Alnemri T, Yu JW, Datta P, Wu J, Alnemri ES: AIM2 activates the inflammasome and cell death in response to cytoplasmic DNA. Nature 2009;458:509-513.

\footnotetext{
6 Hornung V, Ablasser A, Charrel-Dennis M, Bauernfeind F, Horvath G, Caffrey DR, Latz E, Fitzgerald KA: AIM2 recognizes cytosolic dsDNA and forms a caspase-1-activating inflammasome with ASC. Nature 2009;458:514-518.

7 Roberts TL, Idris A, Dunn JA, Kelly GM, Burnton CM, Hodgson S, Hardy LL, Garceau V, Sweet MJ, Ross IL, Hume DA, Stacey KJ: HIN-200 proteins regulate caspase activation in response to foreign cytoplasmic DNA. Science 2009;323:1057-1060.
} 
8 Halle A, Hornung V, Petzold GC, Stewart CR, Monks BG, Reinheckel T, Fitzgerald KA, Latz E, Moore KJ, Golenbock DT: The NALP3 inflammasome is involved in the innate immune response to amyloid- $\beta$. Nat Immunol 2008;9:857-865.

-9 Sharp FA, Ruane D, Claass B, Creagh E, Harris J, Malyala P, Singh M, O'Hagan DT, Petrilli V, Tschopp J, O’Neill LA, Lavelle EC: Uptake of particulate vaccine adjuvants by dendritic cells activates the NALP3 inflammasome. Proc Natl Acad Sci USA 2009;106:870-875.

10 Dostert C, Petrilli V, Van Bruggen R, Steele C, Mossman BT, Tschopp J: Innate immune activation through NALP3 inflammasome sensing of asbestos and silica. Science 2008;320: 674-677.

11 Kumar H, Kumagai Y, Tsuchida T, Koenig PA, Satoh T, Guo Z, Jang MH, Saitoh T, Akira S, Kawai T: Involvement of the NLRP3 inflammasome in innate and humoral adaptive immune responses to fungal $\beta$-glucan. J Immunol 2009; 183:8061-8067.

$\checkmark 12$ Ichinohe T, Lee HK, Ogura Y, Flavell R, Iwasaki A: Inflammasome recognition of influenza virus is essential for adaptive immune responses. J Exp Med 2009;206:79-87.

-13 Dostert C, Guarda G, Romero JF, Menu P, Gross O, Tardivel A, Suva ML, Stehle JC, Kopf M, Stamenkovic I, Corradin G, Tschopp J: Malarial hemozoin is a NALP3 inflammasome activating danger signal. PloS One 2009; 4:e6510.

14 Bryant C, Fitzgerald KA: Molecular mechanisms involved in inflammasome activation. Trends Cell Biol 2009;19:455-464.

-15 Willingham SB, Allen IC, Bergstralh DT, Brickey WJ, Huang MT, Taxman DJ, Duncan JA, Ting JP: NLRP3 (NALP3, Cryopyrin) facilitates in vivo caspase- 1 activation, necrosis, and HMGB1 release via inflammasome-dependent and -independent pathways. J Immunol 2009;183:2008-2015.

-16 Hornung V, Bauernfeind F, Halle A, Samstad EO, Kono H, Rock KL, Fitzgerald KA, Latz E: Silica crystals and aluminum salts activate the NALP3 inflammasome through phagosomal destabilization. Nat Immunol 2008;9:847856.

-17 Li H, Ambade A, Re F: Cutting edge: necrosis activates the NLRP3 inflammasome. J Immunol 2009;183:1528-1532.

- 18 Yazdi AS, Guarda G, Riteau N, Drexler SK, Tardivel A, Couillin I, Tschopp J: Nanoparticles activate the NLR pyrin domain containing 3 (NLRP3) inflammasome and cause pulmonary inflammation through release of IL$1 \alpha$ and IL-1 $\beta$. Proc Natl Acad Sci USA 2010; 107:19449-19454.

19 Lunov O, Syrovets T, Loos C, Nienhaus GU, Mailander V, Landfester K, Rouis M, Simmet T: Amino-functionalized polystyrene nanoparticles activate the NLRP3 inflammasome in human macrophages. ACS Nano 2011;5:9648-9657.

20 Tassi S, Carta S, Vene R, Delfino L, Ciriolo MR, Rubartelli A: Pathogen-induced interleukin-
$1 \beta$ processing and secretion is regulated by a biphasic redox response. J Immunol 2009;183: 1456-1462.

21 Zhou R, Tardivel A, Thorens B, Choi I, Tschopp J: Thioredoxin-interacting protein links oxidative stress to inflammasome activation. Nat Immunol 2010;11:136-140.

22 Cassel SL, Eisenbarth SC, Iyer SS, Sadler JJ, Colegio OR, Tephly LA, Carter AB, Rothman PB, Flavell RA, Sutterwala FS: The NALP3 inflammasome is essential for the development of silicosis. Proc Natl Acad Sci USA 2008;105: 9035-9040.

23 Gross O, Poeck H, Bscheider M, Dostert C, Hannesschlager N, Endres S, Hartmann G, Tardivel A, Schweighoffer E, Tybulewicz V, Mocsai A, Tschopp J, Ruland J: Syk kinase signalling couples to the Nlrp3 inflammasome for anti-fungal host defence. Nature 2009;459: 433-436.

24 Lee GS, Subramanian N, Kim AI, Aksentijevich I, Goldbach-Mansky R, Sacks DB, Germain RN, Kastner DL, Chae JJ: The calciumsensing receptor regulates the NLRP3 inflammasome through $\mathrm{Ca}^{2+}$ and camp. Nature 2012;492:123-127.

25 Murakami T, Ockinger J, Yu J, Byles V, McColl A, Hofer AM, Horng T: Critical role for calcium mobilization in activation of the NLRP3 inflammasome. Proc Natl Acad Sci USA 2012;109:11282-11287.

26 Muruve DA, Petrilli V, Zaiss AK, White LR, Clark SA, Ross PJ, Parks RJ, Tschopp J: The inflammasome recognizes cytosolic microbial and host DNA and triggers an innate immune response. Nature 2008;452:103-107.

27 Ichinohe T, Pang IK, Iwasaki A: Influenza virus activates inflammasomes via its intracellular M2 ion channel. Nat Immunol 2010;11: 404-410.

28 Kanneganti TD: Central roles of NLRS and inflammasomes in viral infection. Nat Rev Immunol 2010;10:688-698.

29 Pontillo A, Brandao LA, Guimaraes RL, Segat L, Athanasakis E, Crovella S: A 3'UTR SNP in NLRP3 gene is associated with susceptibility to HIV-1 infection. J Acquir Immune Defic Syndr 2010;54:236-240.

30 Pontillo A, Silva LT, Oshiro TM, Finazzo C, Crovella S, Duarte AJ: HIV-1 induces NALP3-inflammasome expression and IL-1 $\beta$ secretion in dendritic cells from healthy individuals but not from HIV+ patients. AIDS 2011;25:11-18.

31 Thea DM, Porat R, Nagimbi K, Baangi M, St Louis ME, Kaplan G, Dinarello CA, Keusch GT: Plasma cytokines, cytokine antagonists, and disease progression in African women infected with HIV-1. Ann Intern Med 1996;124: 757-762.

32 Brabers NA, Nottet HS: Role of the pro-inflammatory cytokines TNF- $\alpha$ and IL- $1 \beta$ in HIV-associated dementia. Eur J Clin Invest 2006;36:447-458.

33 Appay V, Sauce D: Immune activation and inflammation in HIV-1 infection: causes and consequences. J Pathol 2008;214:231-241.
34 Xing HQ, Hayakawa H, Izumo K, Kubota R, Gelpi E, Budka H, Izumo S: In vivo expression of proinflammatory cytokines in HIV encephalitis: an analysis of 11 autopsy cases. Neuropathology 2009;29:433-442.

35 Gendelman HE, Orenstein JM, Martin MA Ferrua C, Mitra R, Phipps T, Wahl LA, Lane HC, Fauci AS, Burke DS, et al: Efficient isolation and propagation of human immunodeficiency virus on recombinant colony-stimulating factor 1-treated monocytes. J Exp Med 1988; $167: 1428-1441$.

36 Nitkiewicz J, Chao W, Bentsman G, Li J, Kim SY, Choi SY, Grunig G, Gelbard H, Potash MJ, Volsky DJ: Productive infection of primary murine astrocytes, lymphocytes, and macrophages by human immunodeficiency virus type 1 in culture. J Neurovirol 2004;10:400408

37 Bartz SR, Vodicka MA: Production of hightiter human immunodeficiency virus type 1 pseudotyped with vesicular stomatitis virus glycoprotein. Methods 1997;12:337-342.

38 Aiken C: Pseudotyping human immunodeficiency virus type 1 (HIV-1) by the glycoprotein of vesicular stomatitis virus targets HIV1 entry to an endocytic pathway and suppresses both the requirement for $\mathrm{Nef}$ and the sensitivity to cyclosporin A. J Virol 1997;71: 5871-5877.

-39 El Dirani-Diab R, Andreola ML, Nevinsky G, Tharaud D, Barr PJ, Litvak S, Tarrago-Litvak L: Biochemical characterization of the p51 sub-unit of human immunodeficiency virus reverse transcriptase in homo- and heterodimeric recombinant forms of the enzyme. FEBS Lett 1992;301:23-28.

40 Koh KB, Fujita M, Adachi A: Elimination of HIV-1 plasmid DNA from virus samples obtained from transfection by calcium-phosphate co-precipitation. J Virol Methods 2000; 90:99-102.

41 Mariathasan S, Weiss DS, Newton K, McBride J, O'Rourke K, Roose-Girma M, Lee WP, Weinrauch Y, Monack DM, Dixit VM: Cryopyrin activates the inflammasome in response to toxins and ATP. Nature 2006;440: 228-232.

42 Kanneganti TD, Ozoren N, Body-Malapel M, Amer A, Park JH, Franchi L, Whitfield J, Barchet W, Colonna M, Vandenabeele P, Bertin J, Coyle A, Grant EP, Akira S, Nunez G: Bacterial RNA and small antiviral compounds activate caspase-1 through cryopyrin/Nalp3. Nature 2006;440:233-236.

43 Eigenbrod T, Franchi L, Munoz-Planillo R, Kirschning CJ, Freudenberg MA, Nunez G, Dalpke A: Bacterial RNA mediates activation of caspase- 1 and IL- $1 \beta$ release independently of TLRs 3, 7, 9 and TRIF but is dependent on UNC93B. J Immunol 2012;189:328-336.

44 Heggelund L, Muller F, Lien E, Yndestad A, Ueland T, Kristiansen KI, Espevik T, Aukrust P, Froland SS: Increased expression of Tolllike receptor 2 on monocytes in HIV infection: possible roles in inflammation and viral replication. Clin Infect Dis 2004;39:264-269. 
45 Beignon AS, McKenna K, Skoberne M, Manches O, DaSilva I, Kavanagh DG, Larsson M, Gorelick RJ, Lifson JD, Bhardwaj N: Endocytosis of HIV-1 activates plasmacytoid dendritic cells via Toll-like receptor-viral RNA interactions. J Clin Invest 2005;115:3265-3275.

-46 Rajan JV, Rodriguez D, Miao EA, Aderem A: The NLRP3 inflammasome detects EMCV and VSV infection. J Virol 2011;85:41674172.

-47 Nour AM, Reichelt M, Ku CC, Ho MY, Heineman TC, Arvin AM: Varicella-zoster virus infection triggers formation of an IL-1 $\beta$ processing inflammasome complex. J Biol Chem 2011;286:17921-17933.

-48 Burdette D, Haskett A, Presser L, McRae S, Iqbal J, Waris G: Hepatitis $C$ virus activates interleukin-1 $\beta$ via caspase-1-inflammasome complex. J Gen Virol 2012;93:235-246.

-49 Barlan AU, Griffin TM, McGuire KA, Wiethoff CM: Adenovirus membrane penetration activates the NLRP3 inflammasome. J Virol 2011;85:146-155.
50 Barlan AU, Danthi P, Wiethoff CM: Lysosomal localization and mechanism of membrane penetration influence nonenveloped virus activation of the NLRP3 inflammasome. Virology 2011.

51 McCoy AJ, Koizumi Y, Higa N, Suzuki T: Differential regulation of caspase- 1 activation via NLRP3/NLRC4 inflammasomes mediated by aerolysin and type III secretion system during Aeromonas veronii infection. J Immunol 2010;185:7077-7084.

52 Oosting M, van de Veerdonk FL, Kanneganti TD, Sturm P, Verschueren I, Berende A, van der Meer JW, Kullberg BJ, Netea MG, Joosten LA: Borrelia species induce inflammasome activation and IL-17 production through a caspase-1-dependent mechanism. Eur J Immunol 2011;41:172-181.
53 Gregory SM, Davis BK, West JA, Taxman DJ, Matsuzawa S, Reed JC, Ting JP, Damania B: Discovery of a viral NLR homolog that inhibits the inflammasome. Science 2011;331:330-334.

54 Grebe A, Latz E: Cholesterol crystals and inflammation. Curr Rheumatol Rep 2013;15:313.

55 Duewell P, Kono H, Rayner KJ, Sirois CM, Vladimer G, Bauernfeind FG, Abela GS, Franchi L, Nunez G, Schnurr M, Espevik T, Lien E, Fitzgerald KA, Rock KL, Moore KJ Wright SD, Hornung V, Latz E: NLRP3 inflammasomes are required for atherogenesis and activated by cholesterol crystals. Nature 2010;464:1357-1361.

56 Rajamaki K, Lappalainen J, Oorni K, Valimaki E, Matikainen S, Kovanen PT, Eklund KK: Cholesterol crystals activate the NLRP3 inflammasome in human macrophages: a novel link between cholesterol metabolism and inflammation. PLoS One 2010;5:e11765.

57 Hiscott J, Kwon H, Genin P: Hostile takeovers: viral appropriation of the NF- $\kappa \mathrm{B}$ pathway. J Clin Invest 2001;107:143-151. 